Original Research Paper

\title{
Assessing the Lignin Fraction Extracted from Brazilian Energy Crops
}

\author{
${ }^{1}$ Diogo José Horst, ${ }^{2}$ Jhon Jairo Ramírez Behainne, ${ }^{3}$ Pedro Paulo de Andrade Junior and ${ }^{4}$ Luís Filippe Serpe \\ ${ }^{1,3,4}$ Department of Production Engineering (DAENP), Federal University of Technology-Paraná (UTFPR), Monteiro Lobato \\ Av. km 04, ZIP 84070-000, Ponta Grossa-PR, Brazil \\ ${ }^{2}$ Department of Mechanical Engineering (DAMEC), Federal University of Technology-Paraná (UTFPR), Monteiro Lobato Av \\ km 04, ZIP 84070-000, Ponta Grossa-PR, Brazil
}

Article history

Received: 20-11-2014

Revised: 05-01-2015

Accepted: 08-01-2015

Corresponding Author: Diogo José Horst

Department of Production

Engineering (DAENP), Federal

University of Technology-Paraná

(UTFPR), Monteiro Lobato Av. km

04, ZIP 84070-000, Ponta Grossa-

PR, Brazil

Fax +55(42)3220-4800

Email: diogohorst@hotmail.com

\begin{abstract}
This study quantifies the extraction performance and some properties of the lignin obtained from six crops with potential for generating thermal energy in Brazil. A full factorial design $\left(2^{2}\right)$ with four replicates including two extraction methods and two particles size distributions was adopted for assessing the fraction of lignin, as well as its Higher Heating Value (HHV) and composition given by the proximate and ultimate analysis. It was verified that in all cases the HHV of the lignin is greater than that obtained for the respective raw material, suggesting that these lignins could be also used as fuel in thermochemical processes. The ANOVA analysis showed that at $95 \%$ of confidence level the lignin yield is influenced by the extraction methods, which employ different $\mathrm{pH}$ values during the hydrolysis treatment. In addition, it was found that, in most cases, a smaller biomass particle size contributed to more effective lignin extraction. Response surfaces were also included in order to show tendencies of the lignin yield obtained for each raw material in function of the $\mathrm{pH}$ value used by the extraction method and the biomass particle size range.
\end{abstract}

Keywords: Biomass, Renewable Energy, Lignin Extraction Methods

\section{Introduction}

It is well known that biologically derived fuels may replace part of the traditional fossil fuels consumption, such as oil or coal. Applying agricultural techniques and appropriate strategies for processing, biofuels may offer at least $50 \%$ of savings in atmospheric emissions, when compared to the petroleum derivates. In addition, biofuels produced from crops are considered renewable sources of thermal energy (Serna et al., 2011).

In last year's, the production of green fuels, such as ethanol and others produced from biomass has gained prominence in several countries. If the ethanol industry focused on the second generation in these nations grows, enormous amounts of lignins will be discharged as phenol wastes (Kim et al., 2009). So, lignin is expected to play an important role in the near future, being utilized to produce energy and also by-products (Sena-Martins et al., 2008; Hage et al., 2009; Matsushita et al., 2013).

Currently, lignin is of specialist's interest among the various areas of science and also to benefit the industry, when searching it for new practical applications (Hatfield and Fukushima, 2005; Mansouri and Salvadó, 2007; Wang et al., 2009). However, due to its structural complexity and difficulty of isolation, lignin still waits for more participation in thermochemical processes, such as gasification and pyrolysis (Wang et al., 2009; Hashimoto et al., 2011).

Several works brings contributions about yields and functional groups of lignins, by using several methods such as: Pyrolysis, spectrometry, high performance liquid chromatography, fractionations and separations, among other analytical techniques, which have been previously studied by Lalvani et al. (2000; Celeghini and Lanças, 2001; Demirbas, 2003; 2005; 2009; Yanhua et al., 2004; Huang et al., 2010; Bikovens et al., 2010). Indeed, the available information about the effect of parameters or conditions during the lignin extraction from lignocellulosic materials is scattered and scarce. Some studies have been carried out for straws, husks and leafs of herbaceous crops, but most of reviews are focused on characterization of wood lignins 
(Buranov and Mazza, 2008; Domínguez et al., 2008; Shen et al., 2009; Beis et al., 2010).

In this study the performance of the lignin extraction for six Brazilian crops is in this study the performance of the lignin extraction for six Brazilian crops is thermal conversion processes. Two procedures were tested for lignin extraction using different $\mathrm{pH}$ values, the Klason and Willstatter methods. An experimental factorial planning $\left(2^{2}\right)$ with four replicates was utilized in order to know the relevance of the planning $\left(2^{2}\right)$ with four replicates was utilized in order to know the relevance of the yield, as well as its behavior under different experimental conditions.

\section{Materials and Methods}

The raw material was obtained in farms and food processing industries of Santa Catarina and Paraná states at South of Brazil. Analyses were performed at laboratories of the Santa Catarina State University (UDESC) and the Federal University of Technology-Paraná (UTFPR)/Ponta Grossa. The six assessed biomass were: Wheat straw (Triticum aestivium), corn straw (Zea mays), rice husk (Oryza sativa), sugarcane bagasse (Saccharum officinarum), wood chips (Cedrelinga catenaeformis) and elephant grass (Pennisetum purpureum Schumach.).

The preparation of samples was performed based on the guidelines of the TAPPI $(2007 ; 2012)$ and the ASABE (2011). For raw materials were determined the lignin fractions, extractives and holocellulose, the higher heating values and also the proximate and ultimate analysis. The HHV and the proximate and ultimate analysis were also carried out for the lignin fraction obtained from each raw material.

\section{Feedstock Properties}

The biomass was previously crushed utilizing a knife mill (SOLAB) and then classified in size by using standard sieves of the Tyler mesh series. The Table 1 shows the particles size distributions, including the mean Sauter diameter $(\mathrm{dm})$ value obtained for each biomass.

For test, only two particle size groups were considered. The first group was that collected in sieves with openings from 105 to $500 \mu \mathrm{m}(150$ and 32 Tyler mesh) and second one, in sieves with openings from 1000 to $2000 \mu \mathrm{m}$ (16 and 09 Tyler mesh). The test procedure was based on the ABNT (1982).

In the proximate analysis, the moisture content was determined by utilizing an oven, which was maintained at $110^{\circ} \mathrm{C}$ during $6 \mathrm{~h}$ until no further change in weight occurred. In the volatiles determination, individual samples were placed inside porcelain crucibles with a lid and heated at $850^{\circ} \mathrm{C}$ during 60 min using a vertical muffle furnace (QUIMIS), with capacity to maintain a temperature of $1100^{\circ} \mathrm{C}$. The ash content was determined by using procedure based on the ASTM (2004; 2007). During the test, the samples were kept inside a muffle furnace and heated at $750^{\circ} \mathrm{C}$ during 1 hour until completly arbonized, the fixed carbon was determined by weight difference.

The ultimate analysis was performed by using an automatic chemical analyzer (TRUSPEC-LECO, CHONS). The resolution of the device for the basic elements is: Carbon: 0.3 p.p.m (parts per million) or $0.5 \%$ R.S.D (Relative Standard Deviation), Hydrogen: 100 p.p.m or $1.0 \%$ R.S.D, Nitrogen/Oxygen: 40 p.p.m or $0.5 \%$ R.S.D and sulfur 5 p.p.m or $1 \%$ R.S.D. In tests, 10 $\mathrm{mg}$ of individual samples were evaluated.

\section{Determination of Extractives and Holocellulose}

In the extractives determination, two extractions occurred. First, the samples were exposed to a water bath, which was maintained at $100 \pm 3^{\circ} \mathrm{C}$ during $1 \mathrm{~h}$ with constant stirring, thereby removing the fractions soluble in water. Further, a second solvent extraction was performed, utilizing $10 \mathrm{~g}$ of individual samples and a Soxhlet extraction apparatus (QUIMILAB). The solution was composed of ethanol/cyclohexane and distilled water $(1: 2 \mathrm{v} / \mathrm{v})$. After the extractions, the samples were dried utilizing an oven, which was maintained at $105 \pm 3^{\circ} \mathrm{C}$. The differences in weight after and before the extractions determined the total amount of extractives and the final results were established by considering the total amount of extractives (fractions soluble $\mathrm{n}$ water plus fractions soluble in ethanol/cyclohexane). Test procedure was based on the NREL (2008).

The determination of holocellulose was based on TAPPI (2009; ASTM (1985). In tests, $5 \mathrm{~g}$ of samples already free from extractives were added into a solution composed of nitric acid $\left(\mathrm{HNO}_{3}\right)$, ethanol $(1: 4 \mathrm{v} / \mathrm{v})$ and distilled water. During the test, the samples were kept under constant reflux stirring during $1 \mathrm{~h}$. After this, samples were washed, filtered and dried by using a laboratorial oven, which was maintained at $105^{\circ} \mathrm{C}$ and then weighted utilizing porcelain crucibles with previous weight tare.

\section{Extracting Lignin}

The samples were prepared according the guidelines NREL (2011; TAPPI 2002). Two hydrolysis treatments were used: Klason $\left(\mathrm{H}_{2} \mathrm{SO}_{4}\right)$ and Willstatter $(\mathrm{HCl})$. During tests, $3 \mathrm{~mL}$ of an acid (72\%) was separately diluted and the final concentration of the solution was reduced to $4 \%$ by adding to it $84 \mathrm{~mL}$ of deionized water. The samples were kept in a water bath at $30^{\circ} \mathrm{C}$ during 60 min with constant stirring, thereby performing uniform hydrolysis. The materials were washed and transferred to flasks and at the end of the reaction solids (lignin dark crystals) were obtained using filter papers (WHATMAN-41). The lignins were discharged with final $\mathrm{pH}$ varying between 2 (Klason) and 4 (Willstatter). Samples were washed and dried using an oven, maintained at $105 \pm 3^{\circ} \mathrm{C}$ during $4-6 \mathrm{~h}$ and then weighed. 
Table 1. Mass fraction distribution and particle mean diameter of the biomass samples Mass fraction, $x_{i}(\%)$

\begin{tabular}{|c|c|c|c|c|c|c|c|}
\hline \multirow[b]{2}{*}{$\begin{array}{l}\text { Sieve openings } \\
(\mathrm{mm})\end{array}$} & \multirow[b]{2}{*}{$d_{i}(\mathrm{~mm})$} & & & & & & \\
\hline & & $\begin{array}{l}\text { Sugarcane } \\
\text { bagasse }\end{array}$ & $\begin{array}{l}\text { Corn } \\
\text { straw }\end{array}$ & $\begin{array}{l}\text { Wood } \\
\text { chips }\end{array}$ & $\begin{array}{l}\text { Rice } \\
\text { husk }\end{array}$ & $\begin{array}{l}\text { Elephant- } \\
\text { grass }\end{array}$ & $\begin{array}{l}\text { Wheat } \\
\text { straw }\end{array}$ \\
\hline $2.000-4.000$ & 3.0000 & 0.503 & 0.411 & 0.402 & 0.441 & 0.433 & 0.453 \\
\hline $1.000-2.000$ & 1.5000 & 0.312 & 0.397 & 0.395 & 0.279 & 0.381 & 0.396 \\
\hline $0.500-1.000$ & 0.7500 & 0.125 & 0.162 & 0.119 & 0.178 & 0.131 & 0.112 \\
\hline $0.105-0.500$ & 0.3025 & 0.060 & 0.030 & 0.084 & 0.102 & 0.055 & 0.039 \\
\hline$\Sigma x_{i} / d_{i}$ & & 0.7400 & 0.617 & 0.832 & 0.907 & 0.753 & 0.692 \\
\hline $\mathrm{d}_{\mathrm{m}}(\mathrm{mm})$ & & 1.3500 & 1.620 & 1.200 & 1.100 & 1.330 & 1.450 \\
\hline
\end{tabular}

$x_{i}=$ mass fraction with diameter $d_{i}$

Table 2. Combinations for experimental tests

\begin{tabular}{|c|c|c|c|}
\hline \multirow[b]{2}{*}{ Run } & \multicolumn{2}{|l|}{ Factor } & \multirow[b]{2}{*}{$\begin{array}{l}\text { Response variable, } y_{i} \\
\text { Lignin yield }\end{array}$} \\
\hline & $\begin{array}{l}\text { A } \\
\text { Extraction method }\end{array}$ & $\begin{array}{l}\text { B } \\
\text { Particle size range }(\mu \mathrm{m})\end{array}$ & \\
\hline 1 & Klason $(+1)$ & $1,000-2,000(+1)$ & $y_{1}$ \\
\hline 2 & Klason (+1) & $105-500(-1)$ & $y_{2}$ \\
\hline 3 & Willstatter (-1) & $1,000-2,000(+1)$ & $y_{3}$ \\
\hline 4 & Willstatter $(-1)$ & $105-500(-1)$ & $y_{4}$ \\
\hline
\end{tabular}

\section{Higher Heating Values (HHV)}

The higher heating values of samples of lignin (0.2-0.5 g) were measured utilizing a bomb calorimeter. Samples were burned in pure oxygen atmosphere following procedures of ABNT (1984; ASTM (2000).

\section{Experimental Planning for Lignin Extraction}

The experiments of lignin extraction were planned according a statistical factorial design $\left(2^{2}\right)$. Factorial designs are useful to evaluate the effect estimative of several variables simultaneously, even when using small number of tests. Furthermore, this technique allows finding mathematical correlations between factors and responses. The ANOVA analysis and the response surfaces were generated using the program STATISTICA $^{\mathrm{TM}}$ v.10. The factorial planning (Table 2) considered four replicates for each treatment or combination of controlled factors, totalizing 16 experiments.

\section{Results and Discussion}

The major levels of extractives were obtained utilizing the wheat and corn straws, as well as elephant grass. Regarding the holocellulose content, the major levels were obtained utilizing the wheat, corn straws and rice husks. Table 3 shows the extractives and holocellulose fractions obtained from the each biomass.

Lee et al. (2007; Demirbas, 2009; Guo et al., 2010; Haykiri-Acma et al., 2010; Vargas-Radillo et al., 2011; Rabemanolontsoa and Saka, 2012) found similar levels of extractives and holocellulose for several raw materials. Table 4 shows the results of the proximate analysis for each biomass and its lignin.

The proximate analysis disclosed that the lignins extracted from wood chips and sugarcane bagasse have the highest levels of volatiles and as expected, that of the rice husk presented superior ash fraction. In addition, the lignins obtained from the elephant grass, corn and wheat straws evidenced the major levels of fixed carbon and in all cases, the fixed carbon values in the lignin were higher than those observed for the respective raw material.

Table 5 shows the results of the ultimate analysis for the biomass and lignin samples. The chemical composition of the biomass reported in this study was very similar to those previously searched by Vassilev et al. (2010; Rabemanolontsoa and Saka, 2013). It should be taken into account that differences on the chemical constitution of the materials studied here is conditional to several factors such as: Soil composition, climate, harvest, season, diseases, weeds presence, planting method, spacing, among others; thereby indicating differences even in plants of the same species.

Results of the major added levels of carbon and hydrogen, which influence on the thermal energy potential, were obtained from wood chips. Also, lignins evidenced major levels of carbon than the raw material, as expected. The ultimate analysis discloses that generally, the carbon content of lignins ranges between 50-60\% and from biomass ranges between $40-50 \%$. However, the biomass evidenced major quantities of oxygen $35-45 \%$ and hydrogen $4-7 \%$ than lignins, which presented results ranging from 30-40 and $4-6 \%$, respectively. 
Regarding the possibility of formation of harmful compounds, the ultimate analysis disclosed that remaining fractions of sulfur (from Klason method) and chlorine (from Willstatter method) in lignins could be released when used in thermochemical conversion processes. So, studies focused in quantifying these emissions become essential for the appropriated use of lignin as a fuel during processes of combustion, gasification or pyrolysis. The HHV obtained from both biomass and lignin is showed in Table 6 .

Table 3. Extractives and holocelluloses yields

\begin{tabular}{lllllll}
\hline & Sugarcane bagasse & Corn straw & Wood chips & Rice husks & Elephant-grass & Wheat straw \\
\hline Extractives* (\%) & 13.190 & 13.380 & 9.7100 & 10.050 & 13.670 & 14.170 \\
Holocelluloses*(\%) & 63.662 & 66.187 & 62.862 & 65.987 & 61.862 & 65.712 \\
\hline
\end{tabular}

*dry weight basis

Table 4. Proximate analysis of raw materials and lignins (dry basis)

\begin{tabular}{|c|c|c|c|c|c|c|}
\hline Sample, method and analysis & Sugarcane bagasse & Corn straw & Wood chips & Rice husks & Elephant-grass & Wheat straw \\
\hline \multicolumn{7}{|l|}{ Biomass } \\
\hline Moisture (\%) & 12.90 & 12.64 & 13.55 & 10.91 & 11.18 & 11.90 \\
\hline Volatiles (\%) & 72.33 & 82.77 & 85.61 & 81.63 & 83.25 & 83.90 \\
\hline $\operatorname{Ash}(\%)$ & 10.80 & 1.58 & 0.18 & 10.32 & 10.70 & 9.30 \\
\hline Fixed carbon $(\%)$ & 16.87 & 15.72 & 14.22 & 8.11 & 6.10 & 6.80 \\
\hline \multicolumn{7}{|l|}{ Klason lignin } \\
\hline Volatiles (\%) & 72.81 & 70.18 & 73.46 & 70.02 & 68.44 & 71.28 \\
\hline Ash (\%) & 1.00 & 1.80 & 0.50 & 4.01 & 1.05 & 1.73 \\
\hline Fixed carbon $(\%)$ & 26.19 & 28.02 & 26.04 & 25.97 & 30.51 & 26.99 \\
\hline \multicolumn{7}{|l|}{ Willstatter lignin } \\
\hline Volatiles (\%) & 72.08 & 69.81 & 74.11 & 71.52 & 67.30 & 68.25 \\
\hline Ash $(\%)$ & 0.79 & 1.54 & 0.04 & 3.84 & 1.51 & 1.69 \\
\hline Fixed carbon $(\%)$ & 27.16 & 28.75 & 25.85 & 24.64 & 31.19 & 30.06 \\
\hline
\end{tabular}

Table 5. Ultimate analysis of raw materials and lignins (dry basis)

\begin{tabular}{|c|c|c|c|c|c|c|}
\hline $\begin{array}{l}\text { Sample, method } \\
\text { and analysis }\end{array}$ & $\begin{array}{l}\text { Sugarcane } \\
\text { bagasse }\end{array}$ & Corn straw & Wood chips & Rice husks & Elephant-grass & Wheat straw \\
\hline \multicolumn{7}{|l|}{ Biomass (\%) } \\
\hline $\mathrm{C}$ & 46.80 & 45.40 & 48.06 & 40.10 & 46.70 & 47.50 \\
\hline $\mathrm{H}$ & 5.90 & 6.70 & 6.50 & 4.70 & 5.70 & 5.40 \\
\hline $\mathrm{O}$ & 45.70 & 45.12 & 44.26 & 38.30 & 46.50 & 35.10 \\
\hline $\mathrm{N}$ & 0.50 & 0.90 & 0.80 & 0.40 & 0.20 & 0.60 \\
\hline $\mathrm{S}$ & 0.30 & 0.30 & 0.20 & 0.20 & 0.20 & 0.10 \\
\hline \multicolumn{7}{|l|}{ Klason lignin (\%) } \\
\hline $\mathrm{C}$ & 60.34 & 55.04 & 60.21 & 56.40 & 52.74 & 57.42 \\
\hline $\mathrm{H}$ & 4.10 & 5.58 & 5.28 & 4.82 & 5.14 & 5.10 \\
\hline $\mathrm{O}$ & 34.10 & 37.64 & 32.30 & 37.44 & 40.60 & 35.90 \\
\hline $\mathrm{N}$ & 0.40 & 0.50 & 0.30 & 0.30 & 0.10 & 0.40 \\
\hline S & 1.06 & 1.24 & 1.91 & 1.04 & 1.42 & 1.18 \\
\hline \multicolumn{7}{|c|}{ Willstatter lignin (\%) } \\
\hline $\mathrm{C}$ & 59.32 & 55.70 & 62.21 & 57.02 & 53.66 & 58.01 \\
\hline $\mathrm{H}$ & 4.02 & 5.45 & 4.50 & 4.39 & 4.62 & 6.19 \\
\hline $\mathrm{O}$ & 36.16 & 38.15 & 32.89 & 38.09 & 41.42 & 35.40 \\
\hline $\mathrm{N}$ & 0.30 & 0.40 & 0.10 & 0.30 & 0.10 & 0.30 \\
\hline S & 0.20 & 0.30 & 0.30 & 0.20 & 0.30 & 0.10 \\
\hline
\end{tabular}

Table 6. Higher Heating Values (HHV) of raw materials and lignins, MJ/kg

\begin{tabular}{lllllll}
\hline Determination & Sugarcane bagasse & Corn straw & Wood chips & Rice husks & Elephant-grass & Wheat straw \\
\hline Biomass & 18.07 & 17.63 & 19.78 & 15.84 & 17.50 & 17.99 \\
Klason lignin & 24.64 & 21.48 & 25.73 & 22.16 & 23.17 & 20.61 \\
Willstatter & 22.34 & 20.60 & 24.83 & 21.53 & 21.92 & 20.11
\end{tabular}


Higher heating values for biomass close to those reported in this study were presented by Yan et al. (2009; De Ramos e Paula et al., 2011). Results indicate that the all raw materials have lower HHV values than their lignin fractions, as expected. So, by using appropriated environmental emission control devices, lignin fractions can be important as source of thermal energy. It was noticed that the high carbon and hydrogen levels verified in the ultimate analysis for wood chips and its lignin were in accordance with the most elevated $\mathrm{HHV}$ values attained in both materials.

Table 7 and Fig. 1 show the results of the lignin yield and the effect estimate associated to the two controlled factors for each biomass, respectively.

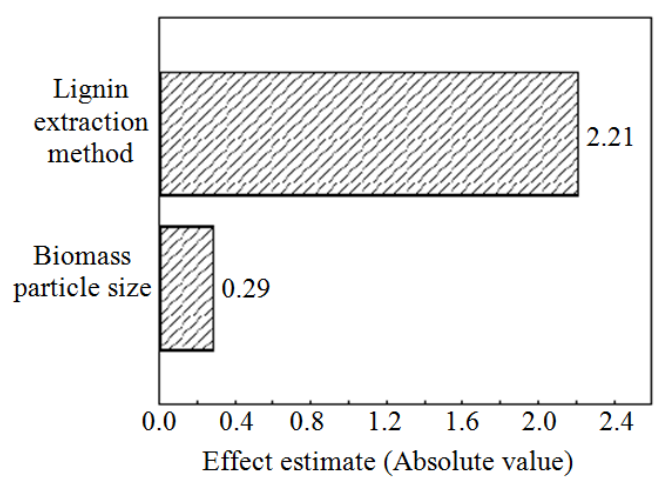

(a)

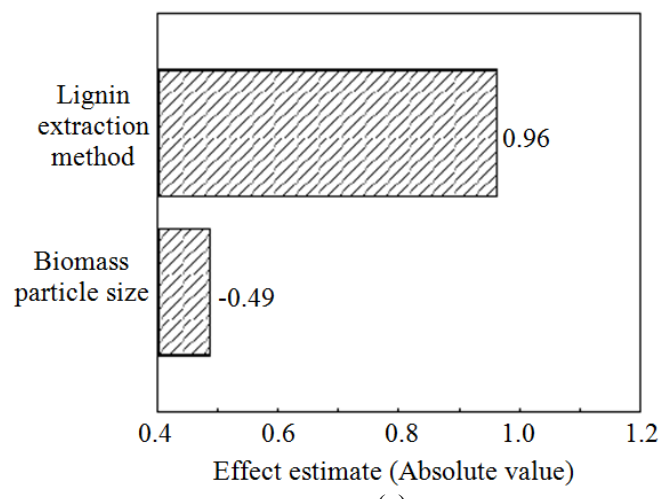

(c)

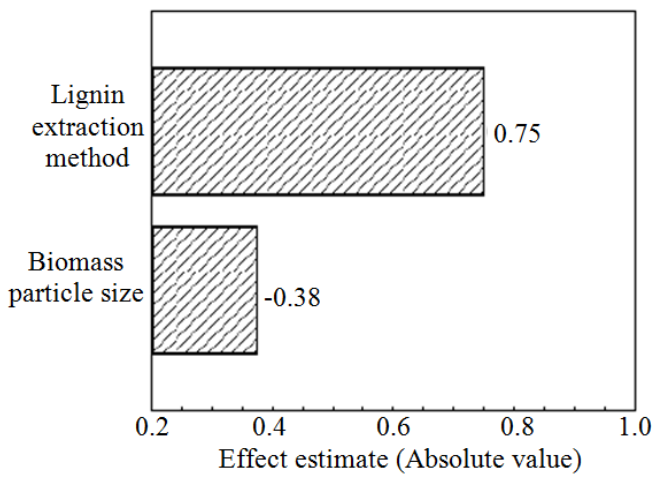

(e)
Figure 1 suggests that for all biomass and conditions analyzed in this study the effect produced by the extraction method is more important that by the particle size. It is also noticed that in most of cases, the group of particle size ranged from 105 to $500 \mu \mathrm{m}$ tends to be more efficient for lignin extraction, once that the effect estimate in such cases was a negative value. This can be explained due to the more exposed superficial area when small particles of biomass are used during the lignin extraction.

In order to know the statistical significance of the extraction method and the biomass particle size on the lignin yield, a ANOVA analysis is presented in Table 8.

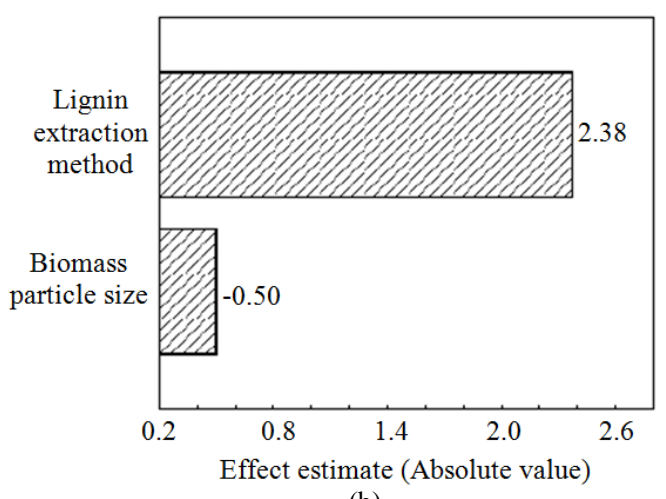

(b)

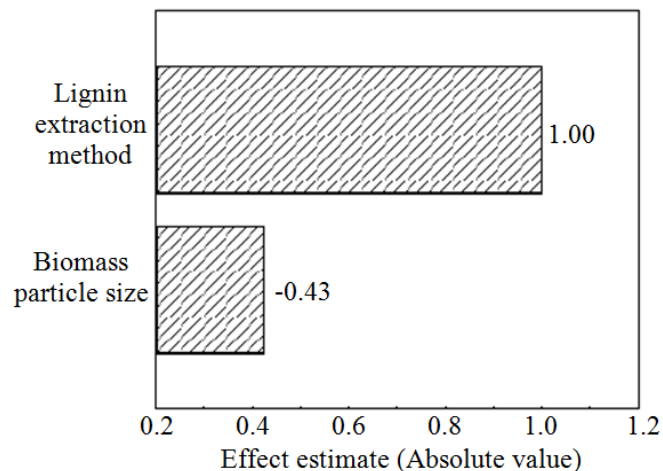

(d)

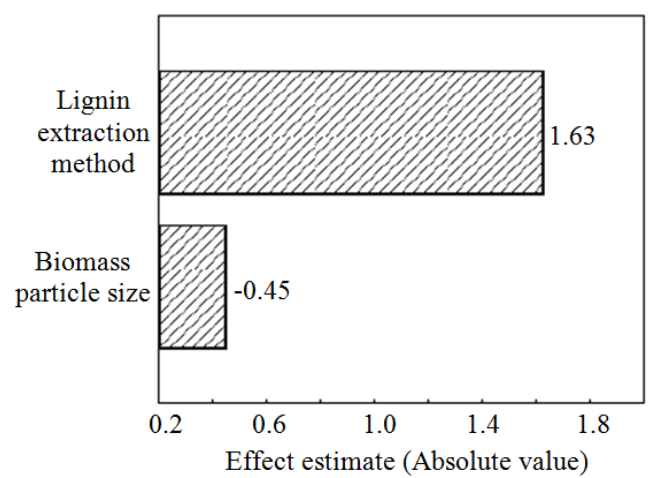

(f)

Fig. 1. Pareto charts of effects: (a) sugarcane bagasse; (b) elephant grass; (c) rice husks; (d) corn straw; (e) wheat straw and (f) wood chips 


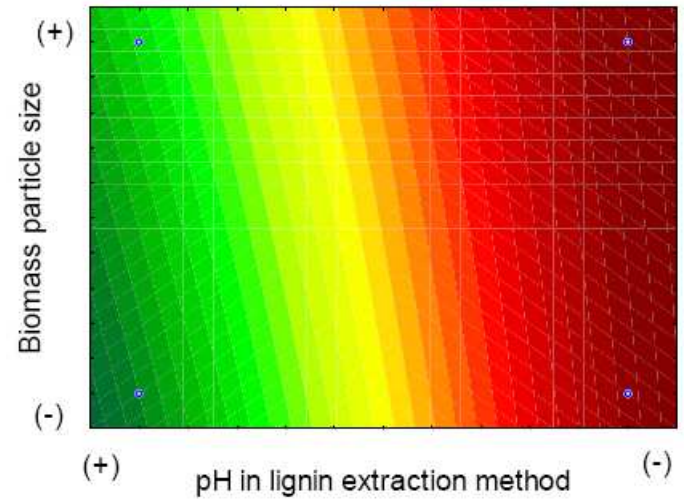

(a)

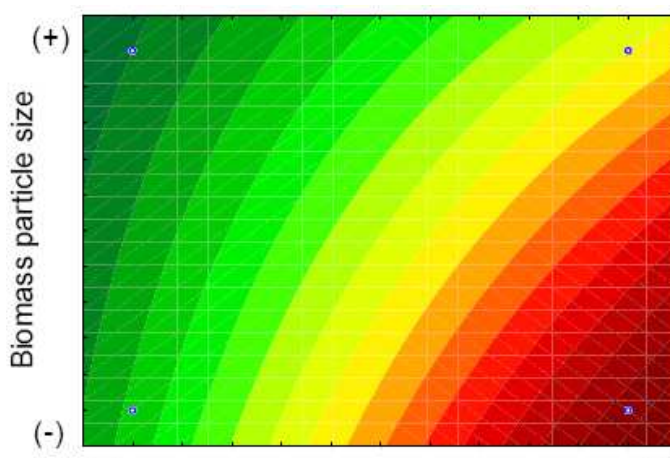

$(+)$

$\mathrm{pH}$ in lignin extraction method

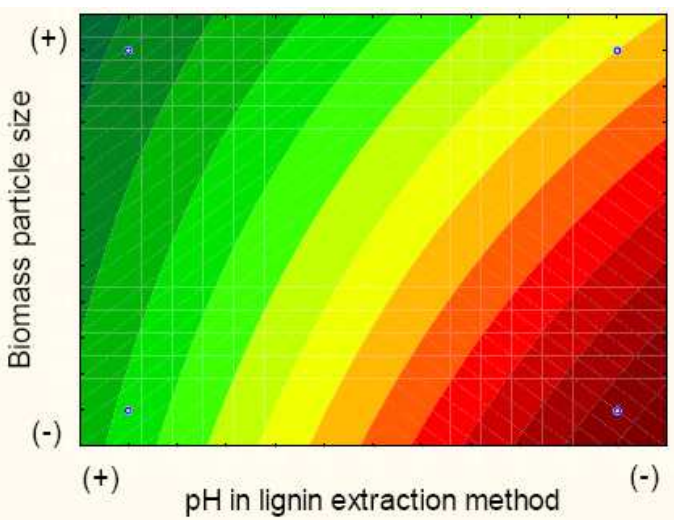

(e)



(b)

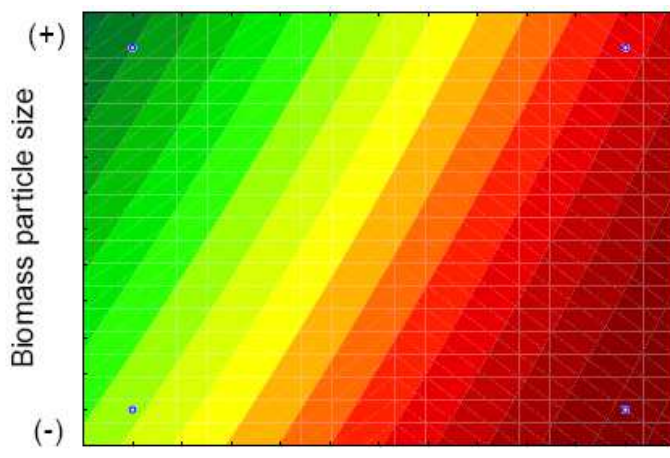

(+) $\quad \mathrm{pH}$ in lignin extraction method

$(-)$

(d)

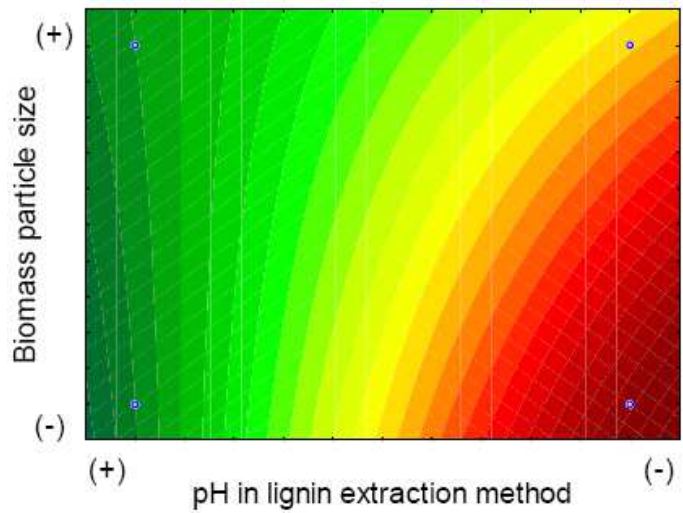

(f)

Fig. 2. Response surfaces: (a) sugarcane bagasse; (b) elephant grass; (c) rice husks; (d) corn straw; (e) wheat straw and (f) wood chips

Results indicate that, at $95 \%$ of confidence level (p-value $\leq 0.05$ ), the lignin yield is affected only by the extraction method in all of cases. In this sense, the extraction carried out through Klason method was always more efficient, once that the effect estimates of Fig. 1 were positive values. This suggests that the lower $\mathrm{pH}$ used in the hydrolysis with the Klason method could improve the lignin extraction. In previous works, Zhu and Theliander (2011;
Agarwal et al., 2011) noticed variations in lignin yields and $\mathrm{HHV}$ values by changing the $\mathrm{pH}$ and temperature during the hydrolysis treatment.

Figure 2 illustrates the surface responses with only tendencies of the lignin yield variation for each biomass in terms of $\mathrm{pH}$ used in the hydrolysis for lignin extraction and the mean biomass particle. More studies are needed in order to make available a more accurate prediction for the lignin yield behavior. 
Diogo José Horst et al. / American Journal of Environmental Sciences 2015, 11 (1): 46.54 DOI: 10.3844/ajessp.2015.46.54

\begin{tabular}{|c|c|c|c|c|c|c|c|c|}
\hline Run & $\begin{array}{l}\text { Extraction } \\
\text { method }\end{array}$ & $\begin{array}{l}\text { Particle size } \\
\text { range }(\mu \mathrm{m})\end{array}$ & $\begin{array}{l}\text { Sugarcane } \\
\text { Bagasse }\end{array}$ & $\begin{array}{l}\text { Corn } \\
\text { straw }\end{array}$ & $\begin{array}{l}\text { Wood } \\
\text { Chips }\end{array}$ & $\begin{array}{l}\text { Rice } \\
\text { Husk }\end{array}$ & $\begin{array}{l}\text { Elephant- } \\
\text { grass }\end{array}$ & $\begin{array}{l}\text { Wheat } \\
\text { straw }\end{array}$ \\
\hline 1 & Klason & $1000-2000$ & 25.4 & 20.9 & 26.5 & 24.9 & 24.4 & 20.0 \\
\hline 2 & Klason & $105-500$ & 25.1 & 21.1 & 28.5 & 25.9 & 25.3 & 20.7 \\
\hline 3 & Willstatter & $1000-2000$ & 22.5 & 20.0 & 25.1 & 23.2 & 22.6 & 19.4 \\
\hline 4 & Willstatter & $105-500$ & 22.2 & 20.1 & 25.9 & 23.4 & 22.5 & 19.6 \\
\hline 5 & Klason & $1000-2000$ & 25.0 & 20.5 & 27.3 & 23.6 & 24.3 & 20.1 \\
\hline 6 & Klason & $105-500$ & 24.9 & 20.7 & 28.4 & 24.1 & 25.3 & 20.5 \\
\hline 7 & Willstatter & $1000-2000$ & 22.1 & 19.4 & 26.9 & 23.0 & 22.5 & 19.5 \\
\hline 8 & Willstatter & $105-500$ & 22.4 & 19.7 & 26.5 & 23.4 & 21.9 & 19.7 \\
\hline 9 & Klason & $1000-2000$ & 24.7 & 20.7 & 27.0 & 23.6 & 23.4 & 20.2 \\
\hline 10 & Klason & $105-500$ & 24.5 & 20.9 & 28.0 & 24.3 & 24.0 & 21.6 \\
\hline 11 & Willstatter & $1000-2000$ & 23.3 & 19.4 & 25.9 & 22.6 & 21.8 & 20.0 \\
\hline 12 & Willstatter & $105-500$ & 22.6 & 20.2 & 25.4 & 22.9 & 21.8 & 20.2 \\
\hline 13 & Klason & $1000-2000$ & 24.5 & 20.5 & 27.1 & 22.7 & 23.4 & 20.5 \\
\hline 14 & Klason & $105-500$ & 24.5 & 21.4 & 27.0 & 23.5 & 26.0 & 20.2 \\
\hline 15 & Willstatter & $1000-2000$ & 23.4 & 19.6 & 25.7 & 23.2 & 22.2 & 19.6 \\
\hline 16 & Willstatter & $105-500$ & 22.4 & 20.3 & 25.4 & 23.2 & 21.8 & 19.8 \\
\hline
\end{tabular}

Table 8 . Analysis of variance for lignin yields

\begin{tabular}{|c|c|c|c|c|c|c|}
\hline Biomass of the lignin & Factor & $\begin{array}{l}\text { Sum of } \\
\text { squares }\end{array}$ & $\begin{array}{l}\text { Degrees of } \\
\text { Freedom }\end{array}$ & $\begin{array}{l}\text { Mean } \\
\text { square }\end{array}$ & F0 & p-value \\
\hline \multirow[t]{4}{*}{ Sugarcane bagasse } & Extraction method & 19.58 & 1 & 19.58 & 117.63 & 0.000 \\
\hline & Biomass particle size & 0.33 & 1 & 0.33 & 1.98 & 0.184 \\
\hline & Error & 1.99 & 12 & 0.16 & & \\
\hline & Total & 21.98 & 15 & & & \\
\hline \multirow[t]{4}{*}{ Elephant-grass } & Extraction method & 22.56 & 1 & 22.56 & 72.68 & 0.000 \\
\hline & Biomass particle size & 1.00 & 1 & 1.00 & 3.22 & 0.097 \\
\hline & Error & 3.72 & 12 & 0.31 & & \\
\hline & Total & 29.69 & 15 & & & \\
\hline \multirow[t]{4}{*}{ Rice husk } & Extraction method & 3.70 & 1 & 3.70 & 7.38 & 0.018 \\
\hline & Biomass particle size & 0.95 & 1 & 0.95 & 1.89 & 0.193 \\
\hline & Error & 6.01 & 12 & 0.50 & & \\
\hline & Total & 10.94 & 15 & & & \\
\hline \multirow[t]{4}{*}{ Corn straw } & Extraction method & 4.00 & 1 & 4.00 & 58.18 & 0.000 \\
\hline & Biomass particle size & 0.72 & 1 & 0.72 & 10.50 & 0.007 \\
\hline & Error & 0.82 & 12 & 0.06 & & \\
\hline & Total & 5.55 & 15 & & & \\
\hline \multirow[t]{4}{*}{ Wood chips } & Extraction method & 10.56 & 1 & 10.56 & 29.78 & 0.000 \\
\hline & Biomass particle size & 0.81 & 1 & 0.81 & 2.28 & 0.156 \\
\hline & Error & 4.25 & 12 & 0.35 & & \\
\hline & Total & 16.83 & 15 & & & \\
\hline \multirow[t]{4}{*}{ Wheat straw } & Extraction method & 2.25 & 1 & 2.25 & 16.41 & 0.001 \\
\hline & Biomass particle size & 0.56 & 1 & 0.56 & 4.10 & 0.065 \\
\hline & Error & 1.64 & 12 & 0.13 & & \\
\hline & Total & 4.58 & 15 & & & \\
\hline
\end{tabular}

\section{Conclusion}

In this study the yield and some properties of lignins obtained from several energy crops grows in Brazil were assessed in function of the lignin extraction method and the biomass particle size. For wheat straw, corn straw, rice husk, sugarcane bagasse, wood chips and elephant grass the proximate and ultimate analysis, as well as, the $\mathrm{HHV}$ values were in accordance with those found in literature. As expected, all biomass showed lower HHV values than their lignin fractions. So, even though important restrictions could be imposed for burning the lignin due to presence of corrosive and pollutant compounds, the HHV values ranged from approximately 20.5 to $24.0 \mathrm{MJ} / \mathrm{kg}$ shows that the lignin obtained from the raw materials has potential as source of thermal energy to be used in thermochemical processes.

By means of a $2^{2}$ factorial design with 16 runs for planning the lignin extraction tests was possible to establish the statistical significance of the effects 
produced by the extraction method and the biomass particle size on the lignin extraction performance. In this sense, it was found that, at $95 \%$ of confidence level, only the extraction method is relevant, suggesting that the Klason procedure is more effective that the Willstatter one. The higher lignin extraction yield obtained with the Klason method was attributed to the lower $\mathrm{pH}$ used in the hydrolysis treatment. On the other hand, the biomass particle size had significant effect on the lignin extraction for some raw materials. In such cases, samples with minor particle size lead to more lignin yield, suggesting the influence of the superficial area in contact during the hydrolysis.

More studies focused in quantifying the emissions and other thermochemical properties of lignins become necessary in order to find alternatives for the safe use as fuel or intensify its application in the petrochemical industry.

\section{Acknowledgement}

The authors thank the financial support offered at this research by the "Coordination for the Improvement of Higher Education Personnel” (CAPES), Brazil.

\section{Author's Contributions}

This study is a result of the full collaboration of all the authors.

Meanwhile, Diogo José Horst: responsible for the collection of samples and laboratorial essays.

Jhon Jairo Ramírez Behainne: Coordinated the data analysis and statistical treatment.

Pedro Paulo de Andrade Junior: Interpreted the data and organized the study by reviewing it critically.

Luís Filippe Serpe: Contributed with the writing and was responsible for the grammar check and final artwork.

\section{Ethics}

The authors declare that this is an original research and do not have any ethical issues or copyrights conflict.

\section{References}

ABNT, 1982. NBR-7402, Charcoal-Granulometric determination, Methods of test, Brasília, D.F., Associação Brasileira de Normas Técnicas.

ABNT, 1984. NBR-8633, Charcoal-determination of calorific values, Brasília, D.F. Associação Brasileira de Normas Técnicas.

Agarwal, U.P., J.Y. Zhu and S.A. Ralph, 2011. Enzymatic hydrolysis of biomass: Effects of crystallinity, particle size and lignin removal. Proceedings, 16th International Symposium on Wood, Fiber and Pulping Chemistry, Jun. 8-10, China Light Industry Press, Tianjin, China, pp: 910-914.
ASABE, 2011. ASABE-S593.1, terminology and definitions for biomass production, harvesting and collection, Storage, Processing, Conversion and Utilization, St. Joseph, MI. American Society of Agricultural and Biological Engineers.

ASTM, 1985. D1104-56-78, Method of test for holocellulose in wood, Withdrawn. American Society for Testing and Materials.

ASTM, 2000. D-2015, Standard test method for gross calorific value of coal and coke by adiabatic bomb calorimeter, Withdraw. American Society for Testing and Materials.

ASTM, 2004. E830-87, Standard Test Method for Ash in the Analysis Sample of Refuse-Derived Fuel, Withdraw, American Society for Testing and Materials.

ASTM, 2007. D1102-84, Standard Test Method for Ash in Wood, Withdraw, American Society for Testing and Materials.

Beis, S.H., S. Mukkamala, N. Hill, J. Joseph and C. Baker et al., 2010. Fast pyrolysis of lignins. BioResources, 5: 1408-1424.

Bikovens, O., G. Telysheva and K. Iiyama, 2010. Comparative studies of Grass compost lignin and the lignin component of compost humic substances. Chem. Ecol., 26: 67-75. DOI: $10.1080 / 02757540.2010 .494600$

Buranov, A.U. and G. Mazza, 2008. Lignin in straw of herbaceous crops. Indus. Crops Prod., 28: 237-259. DOI: 10.1016/j.indcrop.2008.03.008

Celeghini, R.M.S. and F.M. Lanças, 2001. Optimization of the direct liquefaction of lignin obtained from sugar cane bagasse. Energy Sources, 26: 369-375. DOI: $10.1080 / 009083101300110913$

De Ramos e Paula, L.E., P.F. Trugilho, A. Napoli and M.L. Bianchi, 2011. Characterization of residues from plant biomass for use in energy generation. Cerne, 17: 237246. DOI: $10.1590 / \mathrm{S} 0104-77602011000200012$

Demirbas, A., 2003. Relationships between heating value and lignin, fixed carbon and volatile material contents of shells from biomass products. Energy Sources, 25: 629-635. DOI: $10.1080 / 00908310390212336$

Demirbas, A., 2005. Estimating of structural composition of wood and non-wood biomass samples. Energy Sources, 27: 761-767. DOI: 10.1080/00908310490450971

Demirbas, A., 2009. Biohydrogen: For Future Engine Fuel Demands. 1st Edn., Springer, Hardcover, ISBN-10: 1848825110, pp: 287.

Domínguez, J.C., M. Oliet, M.V. Alonso, M.A Gilarranz and F. Rodríguez, 2008. Thermal stability and pyrolysis kinetics of organosolv lignins obtained from Eucalyptus globulus. Indus. Crops Prod., 27: 150-156. DOI: 10.1016/j.indcrop.2007.07.006 
Guo, X.J., S.R. Wang, K.G. Wang, Q. Liu and Z.Y. Luo, 2010. Influence of extractives on mechanism of biomass pyrolysis. J. Fuel Chem. Technol., 38: 4246. DOI: $10.1016 / \mathrm{S} 1872-5813(10) 60019-9$

Hage, R.E., N. Brosse, L. Chrusciel, C. Sanchez and P. Sannigrahi et al., 2009. Characterization of milled wood lignin and ethanol organosolv lignin from miscanthus. Polymer Degradat. Stability, 94: 16321638. DOI: 10.1016/j.polymdegradstab.2009.07.007

Hashimoto, K., I. Hasegawa, J. Hayashi, and K. Mae, 2011. Correlations of kinetic parameters in biomass pyrolysis with solid residue yield and lignin content. Fuel, 90: 104-112. DOI: 10.1016/j.fuel.2010.08.023

Hatfield, R. and R.S. Fukushima, 2005. Can lignin be accurately measured? Crops Sci., 45: 832-839. DOI: $10.2135 /$ cropsci2004.0238

Haykiri-Acma, H., S. Yaman and S. Kucukbayrac, 2010. Comparison of the thermal reactivities of isolated lignin and holocellulose during pyrolysis. Fuel Process. Technol., 91: 759-764. DOI: $10.1016 /$ j.fuproc.2010.02.009

Huang, C., L. Han, X. Liu and L. Ma, 2010. The rapid estimation of cellulose, hemicellulose and lignin contents in rice straw by near infrared spectroscopy. Energy Sources, 33: 114-120. DOI: $10.1080 / 15567030902937127$

Kim, H.S., D.H. Cho, K. Won and Y.H. Kim, 2009. Inactivation of Coprinus cinereus peroxidase during the oxidation of various phenolic compounds originated from lignin. Enzyme Microbiol. Technol., 45: 150-155. DOI: 10.1016/j.enzmictec.2009.05.001

Lalvani, S.B., A. Hubner, T.S. Wiltowski, 2000. Chromium adsorption by lignin. Energy Sources, 22: 45-56. DOI: 10.1080/00908310050014207

Lee, D.K., V.N. Owens, A. Boe and P. Jeranyama, 2007. Composition of Herbaceous Biomass Feedstocks. 1st Edn., North Central Sun Grant Center, Brookings, pp: 16 .

Mansouri, N.E. and J. El Salvadó, 2007. Analytical methods for determining functional groups in various technical lignins. Indus. Crops Prod., 26: 116-124. DOI: 10.1016/j.indcrop.2007.02.006

Matsushita, Y., E.K. Jo., R. Inakoshi, S. Yagami and N. Takamoto et al., 2013. Hydrothermal reaction of sulfuric acid lignin generated as a by-product during bioethanol production using lignocellulosic materials to convert bioactive agents. Indus. Crops Prod., 42: 181-188. DOI: $10.1016 /$ j.indcrop.2012.05.030

NREL, 2008. NREL/TP-510-42619 Determination of Extractives in Biomass, Golden, CO., National Renewable Energy Laboratory.

NREL, 2011. NREL/TP-510-42618, determination of structural carbohydrates and lignin in Biomass, Golden, CO., National Renewable Energy Laboratory.

Rabemanolontsoa, H. and S. Saka, 2012. Holocellulose Determination in Biomass. In: Zero-Carbon Energy Kyoto 2011, Yao, T. (Ed.), Springer, pp: 135-140.
Rabemanolontsoa, H. and S. Saka, 2013. Comparative study on chemical composition of various biomass species. RSC Adv., 3: 3946-3956. DOI: $10.1039 /$ C3RA22958K

Sena-Martins, G., E. Almeida-Vara and J.C. Duarte, 2008. Eco-friendly new products from enzymatically modified industrial lignins. Indus. Crops Prod., 27: 189-195. DOI: 10.1016/j.indcrop.2007.07.016

Serna, F., L. Barrera and H. Montiel, 2011. Impacto social y económico en el uso de biocombustibles. J. Technol. Manage. Innovat., 6: 100-114. DOI: $10.4067 / \mathrm{S} 0718-27242011000100009$

Shen, S., X.S. Wang, M. Garcia-Perez, D. Mourant and M.J. Rhodes et al., 2009. Effects of particle size on the fast pyrolysis of oil mallee woody biomass. Fuel, 88: 1810-1817. DOI: $10.1016 /$ j.fuel.2009.05.001

TAPPI, 2002. T-222 om-06, Acid insoluble lignin in Wood and pulp. TAPPI Test Methods, Atlanta, GA. Technical Association of the Pulp and Paper Industry.

TAPPI, 2007. T-264 om-97, Preparation of wood for chemical analysis, TAPPI Test Methods, Atlanta, GA., Technical Association of the Pulp and Paper Industry.

TAPPI, 2009. T-203 om-93, Alpha, beta and gammacellulose in pulp. TAPPI Test Methods, Atlanta, GA., Technical Association of the Pulp and Paper Industry.

TAPPI, 2012. T-257 om-02, Sampling and preparation wood for analysis. TAPPI Test Methods, Atlanta, GA., Technical Association of the Pulp and Paper Industry.

Vargas-Radillo, V.J.J., M.A. Ruiz-Lópes, R.R. Macías, L.B. Ramírez and P.M. García-Lópes et al., 2011. Fermentable sugars from Lupinus rotundiflorus biomass by concentrated hydrochloric acid hydrolysis. Bioresources, 6: 344-355.

Vassilev, S.V., D. Baxter, L.K. Andersen and C.G. Vassileva, 2010. An overview of the chemical composition of biomass. Fuel, 89: 913-933. DOI: 10.1016/j.fuel.2009.10.022

Wang, S.W.K., Q. Liu, Y. Gu, Z. Luo and K. Cen et al., 2009. Comparison of the pyrolysis behavior of lignins from different tree species. Biotechnol. Adv., 27: 562567. DOI: $10.1016 /$ j.biotechadv.2009.04.010

Yan, W., T.C. Acharjee, C.J. Coronella, and V.R. Vásquez, 2009. Thermal pretreatment of lignocellulosic biomass. Environ. Progress Sustainable Energy, 28: 435-440. DOI: $10.1002 /$ ep. 10385

Yanhua, J., Q. Weihong, L. Zongshi and C. Lubai, 2004. A study on the modified lignosulfonate from lignin. Energy Sources, 26: 409-414. DOI: $10.1080 / 00908310490281528$

Zhu, W. and H. Theliander, 2011. Equilibrium of Lignin Precipitation. Proceedings of the 16th International Symposium on Wood, Fiber and Pulping Chemistry, Jun. 8-10, China Light Industry Press, Tianjin, China. 